\title{
AZ ORSZÁGKOCKÁZATOK MÉRÉSE ÉS KEZELÉSE
}

Pap Máté (biztositási és pénzügyi matematikus-közgazdász, Pénzügyi kockázatmenedzsment szakértö, MOL Group) mpap@mol.hu, Homolya Dániel (pénzügyi közgazdász, a cikk irása idején a MOL Group Csoportszintü Pénzügyi Kockázatmenedzsment vezetöje*, a Károli Gáspár Református Egyetem egyetemi adjunktusa)homolya.daniel@kre.hu

\section{ÖSSZEFOGLALÓ}

A vállalatok külföldi befektetési stratégiájának kialakításakor fontos szempont a kockázati tényezők elemzése, melynek során az országkockázat számszerüsítése kiemelt jelentőségü feladat. Ugyanazért a befektetésért magasabb hozamot várnak el a befektetők a kockázatosabb országokban, mint a kevésbé kockázatos térségekben. A szuverén kockázatot mérő indikátorok és az országkockázati pontozás (rating) egyaránt információt nyújtanak az adott ország kockázati kilátásairól, de a módszertan és az alkalmazhatóság feltételei eltérőek. Cikkünkben hármas célkitűzést fogalmazunk meg. Elsőként bemutatjuk a legelterjedtebb országkockázat-mérési módszereket, majd rávilágítunk az országkockázat és a szuverén kockázat közötti különbségekre. Elemzésünk az IHS Global Insight (GI) oszágkockázatot mérő pontrendszerének és az ötéves szuverén credit default swap (CDS) spreadeknek az összehasonlításán alapszik. Statisztikai eszközökkel keressük a kapcsolatot a GI score és az ötéves szuverén CDS-ek között. Az országkockázat mérése mellett fontos azon eszközök vizsgálata, amelyek hozzájárulnak a kitettségből fakadó kockázatok csökkentéséhez. Cikkünk zárófejezetében átfogó elemzést adunk a politikai kockázati biztosítás piacának termékeiről, a szektort jellemző legújabb tendenciákról.

\section{SUMMARY}

The economic outlook for the future is greatly influenced by long-term corporate investments, where risk indicators are essential inputs for current business decisions. Due to country risk, companies should demand higher returns in some countries, for the same investments, than in others. Sovereign risk and country risk ratings also provide information about the country risk, but the methods are different. The paper has three objectives. The first is to analyse the most common alternatives to measure country risk. The second is to examine the relationship between country risk and sovereign risk, thereafter compare the stability of the two measures. The analysis is based on the IHS Global Insight (GI) score and five-year sovereign credit default swap (CDS) spreads, where we analyse the relationship also between the CDS and GI ratings with statistical tools. Beside measurement it has a key importance how country risk exposure could be mitigated, in which insurance might play crucial role. Finally in our analysis we present the current trends in country and political risk insurance market. 
Kulcsszavak: credit default swap, országkockázat, országkockázati score, politikai kockázati biztosítás, szuverén kockázat

Keywords: credit default swap, country risk, country risk score, political risk insurance, sovereign risk

JEL: B27, C18, D81, G32

DOI: $10.18530 /$ BK.2017.3.12

http://dx.doi.org/1018530/BK.2017.3.12

\section{Bevezetés}

Az elmúlt évtizedekben a kockázatkezelés a pénzügyi közgazdaságtan kiemelt területévé vált. A 90-es évektől kezdődően a pénzügyi dereguláció, innováció és liberalizáció hozzájárult a pénzügyi integráció elmélyüléséhez, a nemzetközi kereskedelem élénküléséhez. A beruházási és befektetési feltételek mellett fontos kockázati tényezővé vált a geopolitikai környezet kiszámíthatósága, stabilitása. A jövőbeni gazdasági kilátásokra nagymértékben hatnak a jelenkor hosszú távú vállalati döntései, ahol a különböző kockázati elemek azonosítása és számszerüsítése a kockázatkezelők meghatározó feladatai közé tartoznak. Az országok különböző kockázati megítélése miatt egy vállalat ugyanazért a befektetésért nagyobb hozamot vár el egy kockázatosabb országban, mint egy kevésbé kockázatosnak számon tartott régióban. Azonban az országkockázat mérésekor, számszerüsítésekor számos kihívással nézünk szembe. Egyrészt az országkockázatot mérő faktorok nagyon sokrétü forrásokból származnak, figyelembe kell vennünk a gazdasági, pénzügyi, politikai tényezőket, valamint a társadalmi, szociális folyamatokat. Továbbá nincs egységes álláspont a szakirodalomban arra vonatkozóan, hogy a különbözö kockázati elemeket hogyan mérjük, a különböző mutatók között mi az optimális súlyozás. Nem egyértelmü, hogy melyek azok az elemek, amelyeket nagyobb, és melyek azok, amelyeket kisebb súllyal érdemes figyelembe venni az országkockázat meghatározásakor. Fontos továbbá az is, hogy az egyes mutatókat, modelleredményeket hogyan értelmezzük. Gyakran szembesülünk azzal a problémával, hogy egy adott országról nagyon kevés elérhető információval rendelkezünk, ami nehezíti az ország modellbe illesztését, az országkockázat meghatározását.

A szuverén kockázat annak a veszélyét számszerűsíti, hogy egy állam nem teljesíti fizetési kötelezettségeit a hitelezői felé. A szuverén kockázatról információt nyújtanak a legismertebb pénzügyi és makrogazdasági mutatók, mint a GPD, az államadósság vagy a költségvetési hiány, ugyanakkor a szuverén kockázat mérésére leggyakrabban használt mutatók a kötvényfelárak és a credit default swap (CDS) felárak. Továbbá a fizetési képesség, valamint a gazdasági teljesítőképesség megítélésére a hitelminősítők adósbeso- 
rolása is fontos támpontot jelenthet. Ezzel szemben az országkockázat mérése általában rating-alapú, ahol a végső kockázati pontszámot számos összetevő súlyozott átlagaként kapjuk. A kockázati faktorok között említhetjük a gazdaság szerkezetét, az integráció mélységét, a makrogazdasági mutatókat, a jogi és szabályozási környezetet, a korrupció mértékét vagy éppen a társadalmi folyamatokat. A politikai kockázat egy ország politikai berendezkedésének stabilitását, a geopolitikai, biztonsági kockázatokat számszerüsíti. A legjelentősebb kérdések, hogy zajlik-e, illetve várható-e fegyveres konfliktus az adott régióban? Mennyire stabil a kormányzat pozíciója, illetve mekkora a korrupció mértéke az adott országban? A fentiek alátámasztják, hogy az országkockázat elemzése során a kvantitatív és kvalitatív eszközöket egyaránt fontos figyelembe venni (Damodaran, 2015).

\section{A politikai kockázatok biztosítási piaca fejlődő tendenciát mutat.}

A kockázat mérése mellett fontos szempont, hogyan tudjuk csökkenteni, mérsékelni a kockázati kitettséget. A pénzügyi fedezeti ügyletek (értékpapírosítás, adósság swap) mellett kiemelt jelentőségű a biztosítási szektor szerepe, ahol különböző megoldások születtek az országkockázatok kezelésére. A politikai kockázatok biztosítási piaca fejlödő tendenciát mutat, egyre kiterjedtebb termékekkel, amelyek hatékony kockázatkezelési eszközzé váltak.

Cikkünk első részében a leggyakoribb országkockázat-mérési módszereket mutatjuk be, majd az országkockázat és szuverén kockázat közötti kapcsolatot vizsgáljuk. Elemzésünk során rávilágítunk, hogy egyes országok esetén szignifikáns különbség áll fenn az eltérő megközelítésű mérési módszerek között. Görögország esetében például a geopolitikai környezet kevésbé kockázatos, mint amit a gazdasági és pénzpiaci mutatók implikálnak. Másrészt vannak olyan országok, például Egyiptom, ahol a kiugróan magas politikai kockázat mérsékeltebben kockázatos gazdasági környezettel társul. Összehasonlításunk alapját az IHS Global Insight (GI) pontrendszere és az ötéves CDS-felár adja. Cikkünk zárófejezetében a leghatékonyabb országkockázat-kezelési módszereket összegezzük, és átfogó képet adunk a politikai kockázat biztosítási piacának legújabb trendjeiről.

\section{Az országkockázat mérése}

\subsection{Szuverén kockázati mutatók}

A szuverén kockázat annak a veszélyét számszerűsíti, hogy egy állam nem teljesíti fizetési kötelezettségeit a hitelezői felé. A leggyakrabban használt piaci indikátorok, amelyek a szuverén hitelkockázatot jellemzik: a szuverén kötvények hozamfelárai az amerikai államkötvény felett és a credit default swap felárak (CDS spreadek) (Iranzo, 2008). Ezen a ponton fontos hangsúlyozni, hogy a szuverén kockázatot mérő mutatószámok nem írják le a teljes országkockázati környezetet, leginkább az adósságteljesítési képesség 
számszerüsítésére koncentrálódnak. Ugyanakkor nem tükrözik a gazdaság egészének teljesítményét vagy a politikai, szabályozói és bürokratikus kockázatokat.

A credit default swap (CDS) az egyik legjelentősebb tőzsdén kívül kereskedett hitelderivatíva, „amelyben két személy, a védelem vevője és a védelem eladója, elcserélik egy harmadik - referenciaterméknek nevezett - termék vagy személy hitelkockázatát.

\section{A credit default swap (CDS) az egyik legjelentősebb tőzsdén kívül kereskedett hitelderivatíva.}

A megegyezésben rögzítik, hogy hitelesemény bekövetkezésekor a védelem eladója kártérítést fizet a védelem vevőjének, cserébe a védelem vevője rendszeres időközönként prémiumot fizet a védelem eladójának lejáratig vagy a hitelesemény bekövetkeztéig" (Gyarmati-Medvegyev, 2011). A legjellemzőbb hitelesemények a csőd, azaz az adós fizetésképtelensége, a nemfizetés, amikor esedékesség lejárta után rövid idővel az adós nem fizet, valamint az adósság megtagadása, amelynek során az adós megtagadja az adósságszolgálat teljesítését (Hull et al, 2003). A CDS szemléltetéséhez tekintsük az ötéves magyar CDS-felárat. Amennyiben az ötéves CDS-felár például 150 bázispont, ez azt jelenti, hogy a szerződésbeli díj évi 1,5 százalék, ami a teljes futamidőre vetítve 750 bázispont (Berman, 2005). Az 1. ábra az ötéves magyar CDS-felárat mutatja tízéves időhorizonton. A 226 bázispontos átlagos CDS-felár mellé magas volatilitás társul. A megfigyelt időtávon a relatív sztenderd hiba 60 százalék, míg a CDS-felár terjedelme 615 bázispont. A kiugró értékek a 2008-as gazdasági válságot követő IMF-tárgyalások időszakával, valamint a 2012-ben bekövetkezett hitelminősítők általi leminősítésekkel azonosíthatóak.

\section{1. ábra: Ötéves magyar CDS-felár}

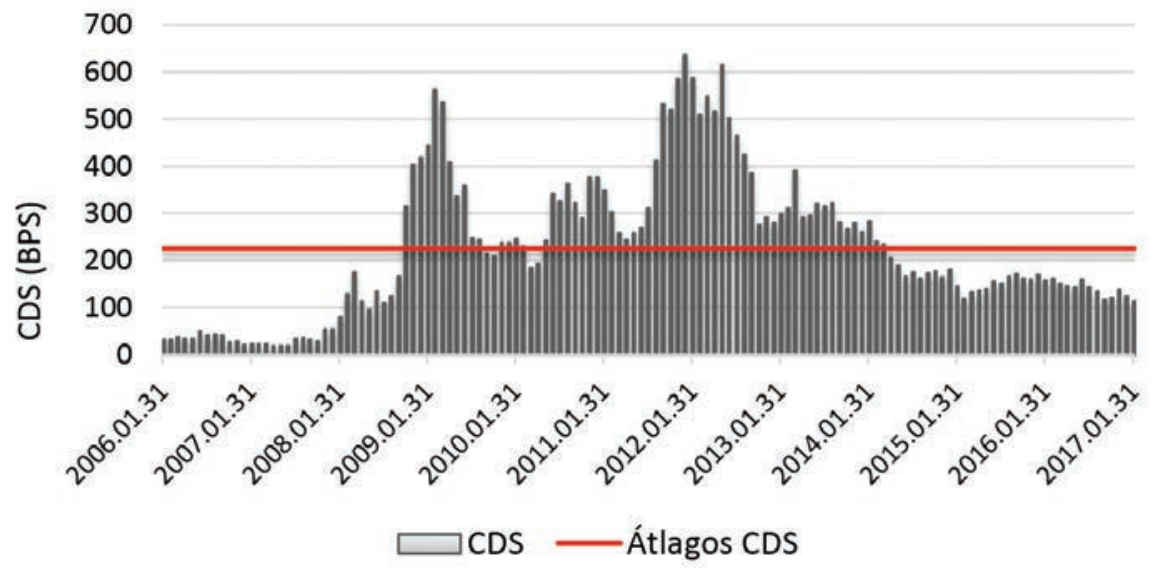

Forrás: saját készités 
A szuverén kockázat megítélésében fontos szerepet játszik a hitelminősítők által közzétett adósbesorolás. A három legjelentősebb („The Big Three”) hitelminősítő a Moody's, a Standard \& Poor's és a Fitch Ratings piaci részesedése 95 százalékot meghaladó. A Moody's saját skálát használ, míg a Standard \& Poors (S\&P) és a Fitch Ratings ugyanazon felosztás alapján értékel (Iranzo, 2008). A Moody’s legjobb minősítése Aaa, ezt követik az Aa, A, Baa, Ba, B és Caa kategóriák. Az S\&P és Fitch esetén a megfelelö kategóriák az AAA (kiváló), AA (nagyon erős), A (erős), BBB (jó hitelképesség), BB (spekulatív), B (erősen spekulatív), CCC, CC, C (magas csődkockázat) és végül a D (csőd). Mindkét módszertan további alkategóriára bontja az egyes kategóriákat, kivétel ez alól a két legjobb minősítés (Aaa és AAA). A Moody’s módszertana az Aa kategóriát Aa1, Aa2 és Aa3, az A kategóriát A1, A2 és A 3 alkategóriákra bontja, és így tovább. Az S\&P és a Fitch az AA+, AA, AA- és így tovább felosztást alkalmaz (Hull et al, 2003). A Baa3 és BBB- ratingek jelentik a befektetésre ajánlott kategóriák alsó határát, az ez alatti minősítéseket spekulatív besorolásoknak tekintjük. Magyarország jelenleg mindhárom hitelminősítőnél befektetésre ajánlott besorolású. Az elmúlt tíz év távlatában a legrosszabb minősítés a Moody’s esetén a Bal volt a 2011 novembere és 2016 novembere közötti időszakban, míg a legjobb A1 2006 szeptemberétől. Az S\&P és Fitch esetén BB és BBB+ ratingek között változott Magyarország kockázati megitélése. Érdemes megemlíteni, hogy a pénzügyi iparág kapcsolódó szabályozásainak (Bázel II/ III a hitelintézetekre, Szolvencia II a biztosítótársaságokra) elöírásaiban, amennyiben nem áll rendelkezésre belső minősítés, akkor a külső minősítéseknek kulcsszerepük van az eszközökhöz kapcsolódó kockázatok meghatározásában.

\subsection{Országkockázati ratingek}

Az országkockázati ratingek meghatározása többnyire kvalitatív módszeren alapszik, ahol a szakértők szubjektív pontokat rendelnek az egyes kockázati tényezőkhöz. A kockázati megítélés gazdasági modellek eredményeinek, piaci adatoknak és az országokról készült riportoknak az összegzése. A végső pontszámot a különböző kockázati faktorok súlyozott átlaga adja. Számos olyan intézmény létezik, amely közzéteszi saját országkockázati ratingjét, kockázati térképét. A biztosítási brókercégek közül például az Aon vagy a Marsh rendszeresen publikálja saját politikai kockázati térképét. Ezen cégek a piaci adatok mellett, tevékenységüknél fogva felhasználhatják saját biztosítási adatbázisukat. Egy ország kockázati elemzése során összegezhetik az adott országban bekövetkezett káresemények számát és volumenét. A Marsh országkockázati indexe (CRI) piaci adatokon és a BMI Research által közzétett elemzéseken alapszik. A különböző kockázati faktorok számszerüsítik a gazdaság állapotát, a politikai kockázatot és a piaci volatilitást. A CRI indexet öt különböző kockázati indikátor súlyozott átlagaként kapjuk. A CRI index összetevői rövid és hosszú távú gazdasági és politikai mutatók, valamint az operációs kockázatot leíró mérőszámok. Az operációs kockázat a Marsh által publikált módszertan szerint a munkaerőpiac, a keres- 
kedelem, a logisztika, valamint a biztonság területén fellelhető kockázatokat számszerüsíti.

A 2. ábrán látható módon a Marsh index öt különböző kockázati kategóriába sorolja az egyes országokat. A legalsó kategóriába az instabil országok tartoznak nagyon magas országkockázattal, míg a 80 és 100 pont között értékelt országok a legkevésbé kockázatosnak tekinthetőek.

\section{A szakértők szubjektív pontokat rendelnek az egyes kockázati tényezőkhöz.}

A Marsh legfrissebben publikált politikai kockázati térképe szerint Észak-Afrika és a Közel-Kelet a leginstabilabb térség, Szíria indexe 25,1, míg Líbiáé 29,9. A legstabilabbnak ítélt országok Svájc és a skandináv államok 80 feletti pontszámmal. Magyarország 67,2 indexszel a középmezőnyben található (Marsh, 2017).

2. ábra: Marsh politikai kockázati kategóriák

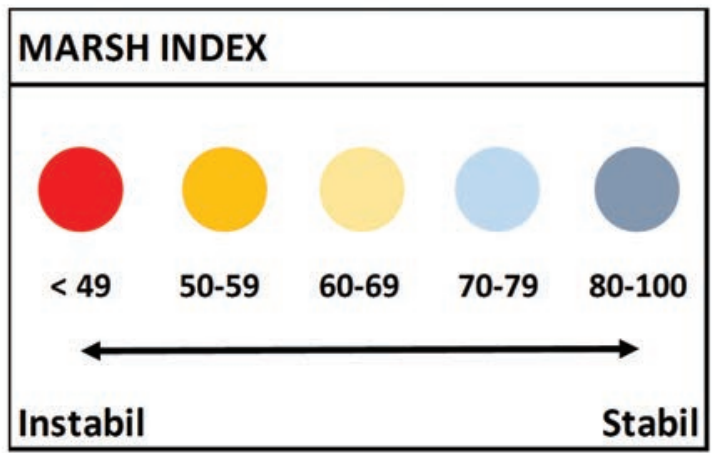

Forrás: Marsh Politikai Kockázati Térkép, 2017

Az IHS és a Heritage Foundation szintén saját metodológia alapján publikálja országkockázati mutatóit. Cikkünk további részében röviden bemutatjuk az IHS által követett módszertant, elemzésünk során pedig felhasználjuk az általuk közzétett GI pontrendszert. Az IHS hat kockázati kategóriára bontja az országkockázatot a következők szerint: megkülönböztet politikai, gazdasági, szabályozói, adózási, operációs és biztonsági kockázatot, amelyeket további alkategóriákra oszt az 1. táblázat szerint.

\section{Az Aon vagy a Marsh rendszeresen publikálja saját politikai kockázati terképét.}

Az IHS módszertana a különböző kockázati komponensekhez egyenlő súlyokat rendel, így a kategóriák pontszámát az alkategóriák, az adott ország végső kockázati pontját pedig a különböző kategóriák súlyozott átlagaként kapjuk (IHS, 2017). 
1. táblázat: Országkockázat összetevői kategóriánként

\begin{tabular}{|c|c|c|c|c|c|}
\hline \multicolumn{2}{|c}{ Politikai } & Gazdasági & Szabályozói & Adózási & \multicolumn{2}{c|}{ Operációs } & Biztonsági \\
\hline $\begin{array}{c}\text { Kormányzati } \\
\text { instabilitás }\end{array}$ & Töketranszfer & $\begin{array}{c}\text { Szerzödéses } \\
\text { végrehajtás }\end{array}$ & Adóinkonzisztencia & Korrupció & $\begin{array}{c}\text { Polgár- } \\
\text { háború }\end{array}$ \\
\hline $\begin{array}{c}\text { Politikai } \\
\text { instabilitás }\end{array}$ & $\begin{array}{c}\text { Valuta- } \\
\text { leértékelés }\end{array}$ & Kisajátitás & Adóemelés & $\begin{array}{c}\text { Infrastruk- } \\
\text { túra }\end{array}$ & $\begin{array}{c}\text { Államközi } \\
\text { háború }\end{array}$ \\
\hline $\begin{array}{c}\text { Államberen- } \\
\text { dezkedés }\end{array}$ & Infláció & $\begin{array}{c}\text { Állami } \\
\text { szerzö- } \\
\text { désmódosítás }\end{array}$ & & Sztrájk & $\begin{array}{c}\text { Tüntetések, } \\
\text { zavargások }\end{array}$ \\
\hline & Recesszió & & & $\begin{array}{c}\text { Bürokratikus } \\
\text { terhek }\end{array}$ & $\begin{array}{c}\text { Terroriz- } \\
\text { mus }\end{array}$ \\
\hline & $\begin{array}{c}\text { Szuverén } \\
\text { csőd }\end{array}$ & & & & \\
\hline & $\begin{array}{c}\text { Foglalkoz- } \\
\text { tatottság }\end{array}$ & & & & \\
\hline
\end{tabular}

Forrás: IHS Strategic Risk Methodology (IHS, 2017)

A politikai kockázat a kormányzat és az államberendezkedés stabilitását méri. Olyan kérdésekre keressük a választ, hogy mekkora valószínüséggel váltja le a kormányt az ellenzék az elkövetkező egy évben? Mekkora az állami befolyás a magánszektor, a monetáris politika területén, vagy mennyire protekcionista a gazdaságpolitika? Az országkockázati összetevők közül a gazdasági kategória méri a makrogazdasági teljesítményt, a növekedési kilátásokat, a fizetőeszköz értékállóságát és a szuverén csődkockázatot. Az operációs kockázat számszerűsíti a korrupció mértékét, a munkavállalói jogi környezetet és a bürokratikus terheket. A biztonsági kategória a fegyveres konfliktusok, terrorcselekmények valószínűségét jeleníti meg. Továbbá külön kockázati kategóriába sorolandó az adókörnyezet kiszámíthatósága, valamint a szabályozói kockázat, amely azállamosításnak, kisajátításnak, a szerződések felmondásának a veszélyét értékeli.

A kockázatot 0 és 10 között terjedő skálán mérik, 0,1-es intervallumokkal. A pontszámok alapján az IHS hét különböző kockázati csoportba sorolja az egyes országokat a 2. táblázatnak megfelelően az alacsonytól az extrém kategóriáig. Az IHS az egyes országokhoz rendelt kockázati értékeket negyedévente vizsgálja felül, figyelembe véve a gazdaság, a geopolitika és az állami működés területén bekövetkező változásokat.

\section{2. táblázat: IHS országkockázati kategóriák}

\begin{tabular}{|l|c|c|c|c|c|c|}
\hline Alacsony & Mérsékelt & Közepes & Magas & $\begin{array}{c}\text { Nagyon } \\
\text { magas }\end{array}$ & Kritik us & Extrém \\
\hline $\mathbf{0 . 1}-\mathbf{0 . 7}$ & $\mathbf{0 . 8}-1.5$ & $1.6-2.3$ & $2.4-3.1$ & $3.2-4.3$ & $4.4-6.4$ & $6.5-10.0$ \\
\hline
\end{tabular}

Forrás: IHS Strategic Risk Methodology (IHS, 2017) 
Az IHS 211 országot sorol be kockázati kategóriákba, és készít róluk átfogó elemzéseket. A legfrissebb riport alapján Szingapúr a legkevésbé kockázatos ország 0,5 ponttal, Szingapúrt követi Új-Zéland, Norvégia és Svájc 0,8-as értékeléssel. A legkritikusabb térség nem meglepő módón a Közel-Kelet, ahol Szíria és Jemen kockázati pontszáma egyaránt 5,9. Magyarország a mérsékelt kategóriába esik, ahol 1,3-as pontszáma megegyezik Szlovénia, Szlovákia vagy éppen Csehország mutatószámával (IHS, 2017).

\section{Adatelemzés}

Országkockázati elemzésünk 62 országot tartalmaz, lefedve a különböző kockázatú térségeket. Célunk, hogy statisztikai eszközökkel összehasonlítsuk az ötéves ország CDS-ek elmúlt féléves átlagát, valamint a legfrissebben közzétett GI pontokat. Adatforrásnak a CDS esetén a Bloomberget, valamint a GI mutató esetén az IHS adatbázisát használjuk, a megfigyelési időszak 2016 júliusától 2016 decemberéig tart. Lineáris regresszióval keressük a kapcsolatot az országkockázati mérőszámok között, ahol a független változó a GI mutató, a függő változó pedig a CDS.

\section{A megfigyelési időszak 2016 júliusától 2016 decemberéig tart.}

A becsült regressziós egyenest az $y=182,53 x-164,48$ egyenlet írja le, amely azt jelenti, hogy 1 egységnyi GI-pont-emelkedés 182,53 bázispont CDS-növekedést indukál. A determinációs együttható (R2 ) megmutatja, hogy a függő változó, azaz a CDS-felár összvarianciájának hány százaléka magyarázható a regresszióval. Esetünkben az R2 értéke 0,5495, ami közepes erősségü, ugyanakkor szignifikáns kapcsolatot mutat a CDS-felár és a GI mérőszám között. A 3. ábrán a megfigyelt országok CDS-felár és GI mutató szerinti eloszlása, valamint a lineáris regresszió eredménye látható.

3. ábra: A CDS-felár és a GI mutató összehasonlítása országonként

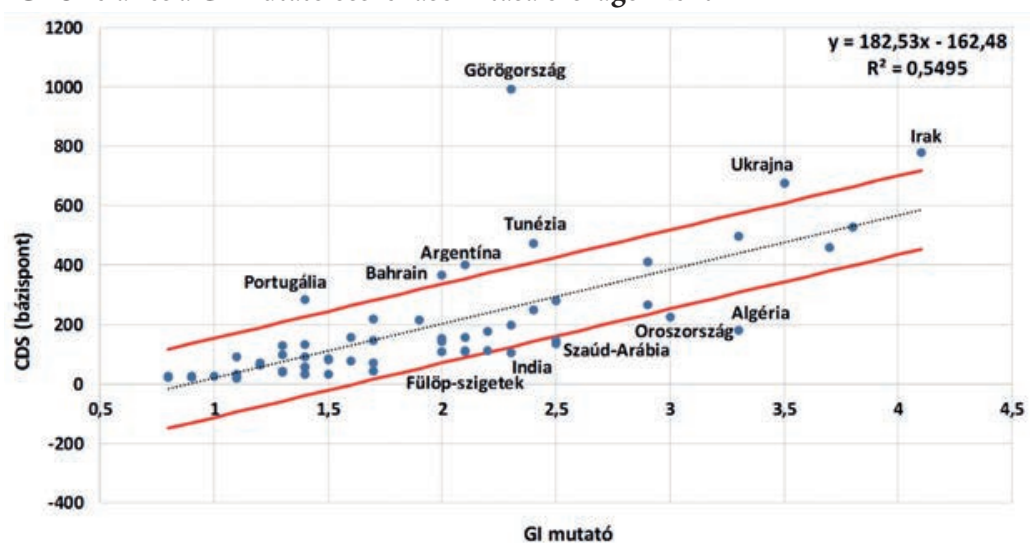

Forrás: saját számítás 
A becsült regressziós egyenest szaggatott vonallal jelöltük, míg a folytonos piros vonalakat a regressziós egyenes 1 sztenderd hibával (133 bázispont) való eltolásával kapjuk. Véleményünk szerint a piros vonalak között elhelyezkedő országok esetén a CDS-felár, valamint a GI mutató nem jelent szignifikánsan eltérő országkockázati besorolást, ugyanakkor az egy szóráson kívül található országok outliernek tekinthetőek. Az egy szórással eltolt egyenes felett fekvő országok, mint Argentína, Görögország, Portugália, Ukrajna vagy Irak esetén a CDS-felár szignifikánsan magasabb, mint amit a megfelelő GI mutató indukálna, a vonal alatti országokra (Oroszország, Szaúd-Arábia, India) pedig a fordítottja igaz. Az első kategóriába tartozó országok nagyon magas pénzügyi kockázatot futnak egy stabilabb geopolitikai környezetben, míg a második kategóriába tartozó országokra a magas politikai kockázat és a kiszámíthatóbb gazdasági kilátások jellemzőek (Barro, 2005, Heinrichs et al, 2012). Fontos vizsgálandó kérdés az is, hogy a két, különböző módszertanon alapuló kockázati mérőszám közül melyik az, amelyik volatilisebb, és melyik az, amelyik hosszú távon stabilabb, kiszámíthatóbb országkockázati besorolást biztosít. A 4. ábra tízéves időtávon mutatja az ötéves magyar CDS-felár és GI pont alakulását. Összehasonlítva a mérőszámok relatív szórását a CDS-felárra, jóval volatilisebb mutatót kapunk 60 százalékos relatív szórással, a GI pont esetén ez a statisztikai paraméter 11 százalék. Az eredmény azt mutatja, hogy a GI pont kevésbéérzékeny a gazdasági vagy pénzügyi sokkok esetén, így egy adott országról általánosabb geopolitikai képet biztosít. Az $y=182,53 x-164,48$ regressziós egyenes segítségével implicit CDS-felárat becsülhetünk a megfelelő GI pontokból indulva. A 4. ábrán Magyarország esetén látható, hogy a pirossal jelölt implicit CDS-felár idősora szignifikánsan alacsonyabb értéket mutat, mint a sárgával jelölt piaci CDS. A 2007 és 2016 között vizsgált időszakban azt láthatjuk, hogy a gazdasági, pénzügyi válságok tetőzésekor a legnagyobb a különbség az implicit és a piaci CDS-felár között, míg a válság enyhülésével a két mutató konvergál egymáshoz. Következésképp stabilabb gazdasági környezet esetén a regressziós becslésünk jobb illeszkedést mutat a CDS-felár és GI mutató közötti kapcsolat leírására.

\section{4. ábra: A magyar CDS-felár és GI mutató összehasonlítása}

\section{MAGYARORSZÁG}

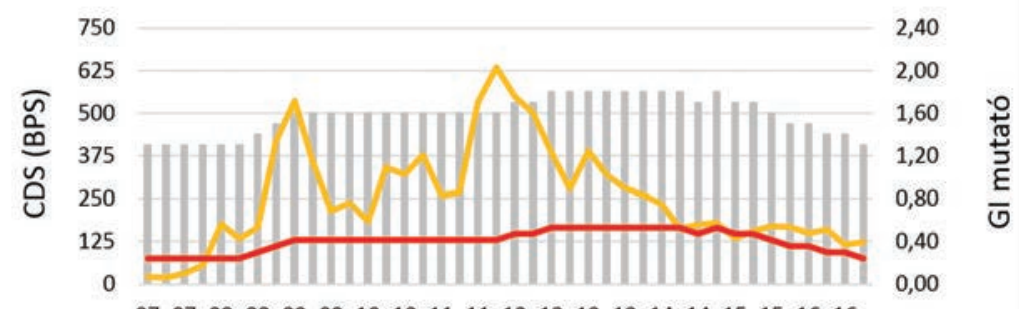

$\begin{array}{llllllllllllllllllll}07 & 07 & 08 & 08 & 09 & 09 & 10 & 10 & 11 & 11 & 12 & 12 & 13 & 13 & 14 & 14 & 15 & 15 & 16 & 16\end{array}$ Q1 Q3 Q1 Q3 Q1 Q3 Q1 Q3 Q1 Q3 Q1 Q3 Q1 Q3 Q1 Q3 Q1 Q3 Q1 Q3

GI mutató —CDS (bps) —Implicit CDS (bps)

Forrás: saját készités 
Azonban a vizsgált országok között találunk olyat is, ahol a GI mutatóból visszaszámolt implicit CDS jóval magasabb a piaci CDS-felárnál. Az 5. ábra tanúsága szerint ezt tapasztaljuk például Egyiptom esetében a 2013 és 2015 negyedik negyedévét átfogó időszak alatt. Ez azt jelenti, hogy a politikai környezet jóval nagyobb kockázatot hordoz magában, mint a gazdasági tényezők. A jelenség az arab tavaszt követő politikai és társadalmi krízissel magyarázható, amikor katonai puccsok, tüntetések, lázadások és politikai megtorlások jellemezték az országot. A megfigyelt és kiugrónak tekintett országok közül érdemes megemlíteni Görögországot, ahol a félbeszakadt IMF-tárgyalásokat követően a szuverén CDS-felár néhány nap alatt a hatszorosára emelkedett, meghaladva a 6000 bázispontot. Ahogy a 6. ábrán láthatjuk, ebben az időszakban a CDS-felár és a GI pont között alacsony korreláció mutatkozik. A krízis csillapodásával a görög CDS-felár még mindig kiugróan magas az Európai Unió többi országához képest, 1000 bázispont körüli értéket mutat.

\section{5. ábra: Az egyiptomi CDS-felár és GI mutató összehasonlítása}

\section{EGYIPTOM}

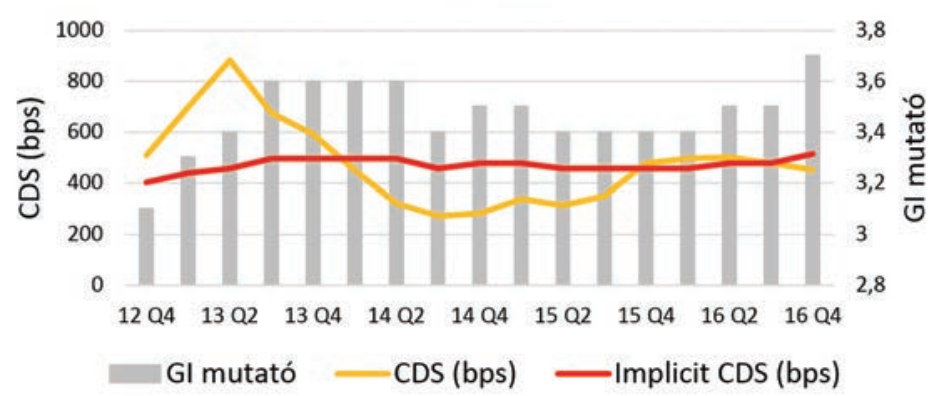

Forrás: saját készités

6. ábra: A görög CDS-felár és GI mutató összehasonlítása

\section{GÖRÖGORSZÁG}

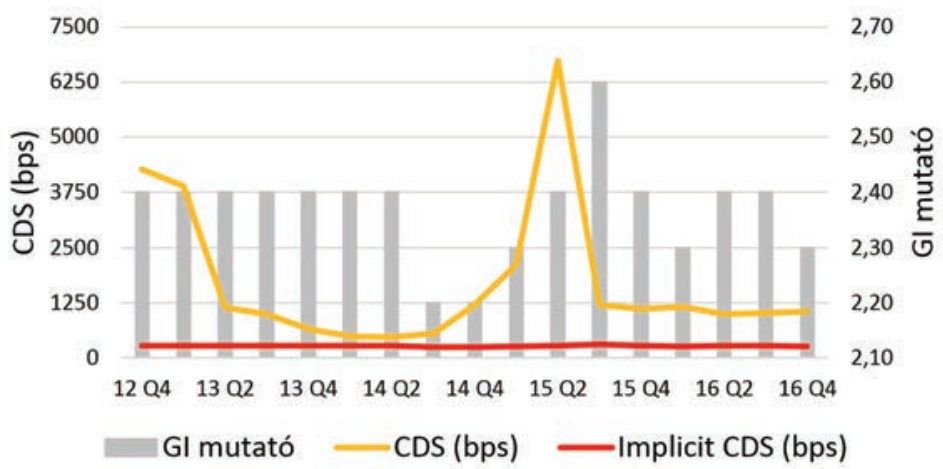

Forrás: saját készités 
Az elözőekben láthattuk, hogy Magyarország és Egyiptom esetén a pénzügyi, illetve politikai konszolidációt követően a piaci és a regressziós egyenletből számolt implicit CDS-felár konvergál egymáshoz. Ugyanakkor a görög piaci CDS tartósan magasabb értéket mutat, mint amit az országkockázatot leíró GI pont indukálna. Ez a tény megerősíti azt a feltételezésünket, hogy a GI mutató kevésbé volatilis a gazdasági és pénzügyi sokkok bekövetkezésekor. Továbbá megjegyzendő, hogy a GI mutatóból visszaszámolt implicit CDS a fundamentumokat jobban megragadó felármutatóhoz vezethet.

\section{Az egyik leggyakrabban alkalmazott diszkontráta a súlyozott átlagos tőkeköltség.}

Számba véve a kockázatkezelési eszközöket, beszélhetünk közvetlen és közvetett eszközökröl. Közvetett eszközöknek azokat az eszközöket tekintjük, amelyek ösztönzők segítségével alakítják az üzleti döntéseket. Az üzleti döntések közvetett ösztönzői között olyan diszkontrátákat alkalmaznak, amelyek segítségével a diszkontált cash-flow modellekben (DCF) meghatározzák a jövőbeli projektek jelenértékét és a jelenlegi eszközök potenciális megtérülését, figyelembe véve a pénz időértékét, illetve az ország- és iparágspecifikus kockázatok hatását az elörejelzett pénzáramlásokra. A projektértékelések során az egyik leggyakrabban alkalmazott diszkontráta a súlyozott átlagos tőkeköltség (weighted average cost of capital, WACC), amely a saját tőke és idegen tőke költségének súlyozott átlaga. A WACC számszerüsíti az általános üzleti kockázati környezetet iparáganként, ugyanakkor a diszkontráta meghatározásakor figyelembe kell venni az országkockázati tényezőket is. Következésképpen a diszkontráta megadható a WACC és az országkockázati prémium összegeként (Brealey-Myers, 1996). Ugyanakkor az országkockázati prémium számítására nincsen egységesen elfogadott, sztenderdizált módszertan. A szakirodalomban számos különböző eljárással, szakértői megközelítéssel találkozunk, köztük a fenti könyv 2. fejezetében bemutatott piaci alapú (CDS-felár, szuverén kötvényfelár) és rating-alapú (IHS GI mutató) országkockázati értékelésekkel. Éppen ezért óvatosnak kell lennünk, hogy kellően robusztus kockázati mértékeket használjunk az elemzés során. Fontos továbbá figyelembe venni, hogy az ösztönzők csak kellően diverzifikált befektetési portfólió esetén müködhetnek jól, nem-diverzifikált portfóliók esetén limitált hatásuk lehet. Mivel sok vállalatnak nincsen diverzifikált befektetési portfóliója, így nagyobb részt közvetlenebb kockázatkezelő eszközöket kell figyelembe venni. A következő fejezetben a közvetlen kockázatkezelési technikákat vizsgáljuk meg, és mutatjuk be részletesebben.

\section{Kockázati eszközök}

A nemzetközi tőkebefektetések során meghatározott vállalati stratégiát - a piaci és üzleti feltételek mellett - nagymértékben befolyásolja a geopolitikai környezet is. A jövőbeli gazdasági kilátások alakulására jelentős hatással bírnak a hosszú távú vállalati beruházások, ahol a különböző kockázati faktorok azonosítása és értékelése fontos 
döntéselőkészítő folyamat. Az elmúlt időszak növekvő geopolitikai bizonytalanságai miatt - mint például a szíriai háború, a Brexit vagy az Oroszországgal szemben alkalmazott gazdasági szankciók - a befektetők és hitelezők számára kiemelt jelentőségűvé váltak a politikai kockázatok csökkentésére irányuló eszközök. A különböző országkockázati tényezők kezelésére számos pénzügyi és intézményi eszköz áll a befektetők rendelkezésére.

A politikai kockázatokkal szemben védelmet nyújtó biztosítási garanciák mellett léteznek különböző társfinanszírozási programok és piaci alapú pénzügyi megoldások (eszközkereskedés, értékpapírosítás, adósság swap) is, amelyek hatékonyan kezelik a befektetési bizonytalanságból fakadó kockázatokat. A 7. ábra a leggyakrabban alkalmazott kockázatkezelési eszközöket szemlélteti (Bouchet et al, 2003). A gazdasági és pénzügyi válságok következtében egyre szélesebb körben terjedtek el a pénzpiaci alapú megoldások, amelyek hatékony védelmet biztosítanak a piaci volatilitások és szuverén csődkockázatok ellen, ugyanakkor kevésbé kezelik a geopolitikai kockázatokat. Cikkünk következő fejezetében átfogó képet adunk a politikai kockázatok biztosítási piacáról, amely piacon kínált termékek alkalmasak az üzleti tevékenység során felmerülö geopolitikai kockázatok mérséklésére.

\section{7. ábra: Kockázatcsökkentő eszközök}

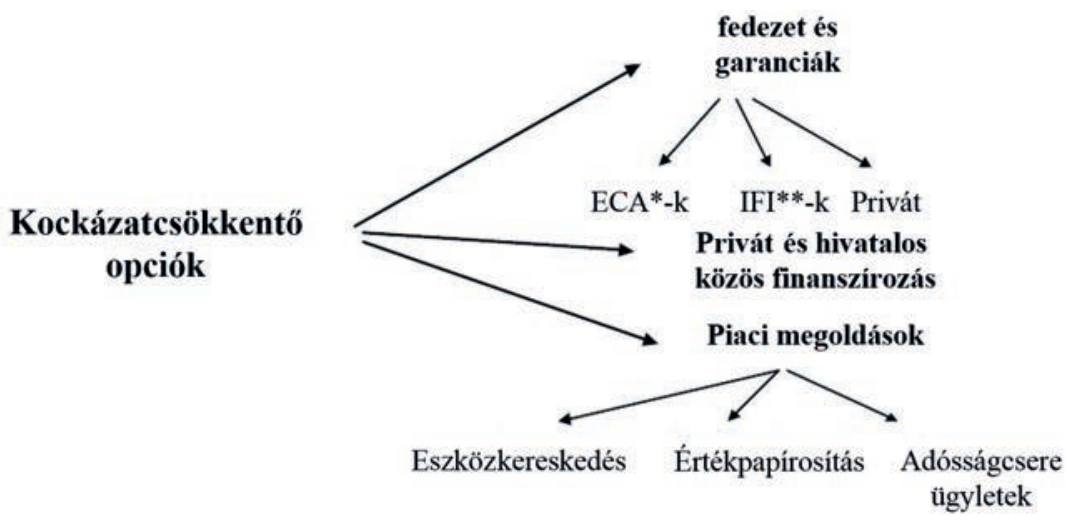

Megjegyzés: * ECA = Export Credit Agency - Export Hitel Ügynökség (például Magyarországon az Exim/MEHIB csoport); ${ }^{*} I F I$ = International Financial Institution - Nemzetközi Pénzügyi Intézmény (pl. EBRD, EIB stb.) Forrás: Country Risk Assessment: A Guide to Global Investment Strategy, p. 198. (Bouchet et al, 2003)

\subsection{A politikai kockázatok biztosítási piaca}

A politikai kockázatok biztosítási piaca (a nemzetközi szaknyelv a PRI rövidítést használja, ami a Political Risk Insurance-t rövidíti, magyarul a PKB rövidítést használhatjuk) magában foglalja az exporthitel-ügynökségeket, a nemzetközi államok felett 
álló, multilaterális és magántulajdonú biztosítókat, amelyek exportra, kereskedelmi hitelre és befektetésekre vonatkozó biztosítást kínálnak, mint ahogy a 7. ábra szemlélteti. Az ilyen típusú biztosítási szolgáltatások olyan, leginkább nem kereskedelmi kockázatokat fedeznek, mint a fogadó kormányok közvetlen és közvetett beavatkozása és nemfizetéssel kapcsolatos esetei. A következőkben a politikai kockázatok egy lehetséges klasszifikációját mutatjuk be, szemléltetve a PKB biztosítási ág által biztosítható kockázatokat. Fontos ugyanakkor hangsúlyozni, hogy egyes biztosítási szereplők terminológiája között eltérés lehet. Az egyik lehetséges megbontás három fő kockázati kategóriát emel ki (MIGA, 2013). A kisajátítás vagy államosítás elleni biztosítás az olyan kormányzati beavatkozás ellen nyújthat védelmet, amely csökkenti vagy akár teljesen el is veheti a biztosított irányítási és tulajdonosi jogait tőkebefektetése során. Eszközök vagy projekttársaságokhoz kapcsolódó tőkebefektetések kompenzáció nélküli kisajátítása, elkobzása és államosítása jelentős negatív hatással járhat külföldi befektetések során (Kansal, 2015). A második kockázati kategória a devizakockázatot és a kiutalási korlátozások kockázatát fedi. Szélsőségesen magasan ingadozó környezet vagy a politikai szankciók növelik a deviza konvertibilitásának, felfüggesztésének kockázatát, amikor egy adott deviza nem váltható át más fizetőeszközre. Egy valutaválság következtében a befektetők nem képesek megfelelni külső adósság-visszafizetési kötelezettségeiknek. A devizakockázat kiterjed a leértékelés kockázatára is, ami csökkenti a külföldi befektetés várható hozamát. A tőkekontrollok bevezetése kiterjed a határon átnyúló átutalások korlátozására, kereskedelmi korlátokra, tőke és osztalék kiutalhatóságának korlátozására, tőkemozgásokhoz kapcsolódó utalások késedelmére és kamatfizetések felfüggesztésére. Végül harmadik kategóriaként a PKB szektor védelmet nyújthat politikai büncselekmények és felkelések okozta károk ellen, beleértve a háborúkat, fegyveres konfliktusokat, megszállást, terrorizmust, polgárháborút, polgári zavargásokat, felkelést, lázadást, forradalmat és sztrájkokat (Kansal, 2015, MIGA, 2013).

A PKB biztosítási ág piaci jellegü szereplői az állami többségi tulajdonban lévő exporthitel-ügynökségek, a multilaterális intézmények, a privát hitelbiztosítók és a viszontbiztosítók. A közösségi PKB biztosítási piac tartalmazza az állami és multilaterális politikai biztosítási szolgáltatókat, míg a magánpiaci PKB üzletágban két különböző kategória különböztethető meg. Az első kategória a politikai kockázati tevékenységből származó kockázati tényezőket (mint pl. háború, terrorizmus, polgári zavargások), valamint a fizetések kiutalásának kockázatát tartalmazza. A második kategória a nemfizetési eseteket és szuverén csőd eseteket fedi (MIGA, 2013).

A Berne Unió (Berne Union - BU) a befektetővédelmi biztosítások és exporthitel-ügynökségek vezető szövetsége. Ezt a nemzetközi, nonprofit szervezetet 1934-ben alapították a globális kereskedelmi és befektetési tevékenységek exporthitellel, kereskedelmi finanszírozással és befektetési eszközökkel történő támogatására. A szövetség céljai között szerepel a határokon átnyúló kereskedelmi tevékenységek élénkítése, az exporthitelekhez és külföldi befektetésekhez kapcsolódó alapelvek sztenderdizálása, 
és információmegosztás a tagszervezetek között. 2016 végén a Berne Uniónak 84 tagja volt: kormányzati hátterü, hivatalos exporthitel-ügynökségek, magántulajdonú hitelbiztosítók, politikai kockázati biztosítók és multilaterális (nemzetközi együttműködésen alapuló) intézmények. 2016-ban a BU tagjai összesen 1865 milliárd USA dollárnyi fedezetet biztosítottak bankoknak, exportálóknak és befektetőknek. Ez a volumen a teljes, határokon átnyúló nemzetközi áru- és szolgáltatáskereskedelem 10 százalékát teszi ki (Berne Union, 2016).

\section{A legtöbb OECD-ország létrehozta a saját, többségi állami tulajdonú exporthitel-ügynökségét.}

Az export és a nemzetközi befektetések élénkítése érdekében a leg több OECD-ország létrehozta a saját, többségi állami tulajdonú exporthitel-ügynökségét (Export Credit Agency = ECA). Az exporthitel segít a nemzeti kormányok azon céljainak támogatásában, miszerint növekedjen a hazai üzleti tevékenység, a foglalkoztatottsági mutatók javuljanak, valamint az adott ország geopolitikai befolyása erősödjön. Az ECA-knak fontos szerepük van a kockázatos földrajzi területek finanszírozási hiányának (finanszírozási hiány (gap) = finanszírozási szükséglet - rendelkezésre álló finanszírozás) részleges lefedésében, ahol a hagyományos kereskedelmi bankok nem finanszíroznak új üzleti területeket. Az ECA-k a nemzetközi befektetők kockázatát exporthitel-garanciák nyújtásával tudják csökkenteni, így téve az exporthitelbankokat a piaci finanszírozás fontos szereplőjévé. Az ECA-k háromféle eszközzel biztosítanak általában forrást külföldi befektetésekhez (Bouchet et al, 2003):

- Közvetlen hitelnyújtás áruk és szolgáltatások megvásárlására a fogadó országban. Ez jelentheti a fogadó országbeli fél fizetéséből származó, várt pénzáramlás előfinanszírozását (exporthitel) vagy az importáló fél külföldi partner felé történő fizetésének előfinanszírozását (importhitel).

- Az export-import bankok katalizátor szerepet tölthetnek be nagy projektekhez kapcsolódó tőkeigény összeszervezésében a kereskedelmi banki kapacitások bevonásának elősegítésével nehéz piacokon (az ECA-k kockázatvállalása a részvétel kockázatát már vállalható szintre csökkentheti a piaci szereplők számára). Az ECA-k az importáló vagy exportáló vállalatok számára történő finanszírozás fejében a pénzügyi közvetítők (pl. kereskedelmi bankok) számára finanszírozást biztosítanak.

- A harmadik megoldás az úgynevezett kamatkiegyenlítési mechanizmus, melynek során az export-import bank támogatást fizet a kereskedelmi hitelezőnek, amely így az importáló/exportáló vállalatoknak piaci kamatozás alatti kamaton tud hitelt biztosítani.

A finanszírozáson túl az ECA-knak kiemelt szerepük van a kereskedelmi banki finanszírozás mellé nyújtott biztosítások kínálatában, mely szektort részletesen a következő fejezetben elemezzük. A Berne Unióban a legfontosabb ECA tagok a következők: 
SINOSURE (Kína), NEXI (Japán), KSURE (Dél-Korea), CESCE (Spanyolo.), COFACE (Franciao.), Euler Hermes (Németo.), EXIAR (Oroszo.), SACE (Olaszország), UK EXPORT FINANCE (Egyesült Királyság) és az US EXIMBANK (Amerikai Egyesült Államok) (The Berne Union, 2016).

A PKB biztosítási szektor privát szereplőinek többsége a három biztosítási központ egyikében található: London, Bermuda és New York. Emellett a legnagyobb releváns biztositótársaságoknak Szingapúrban, Hongkongban és Kínában is van irodájuk. A PKB szektor privát szereplői között 20 Lloyd's szindikátus és 8 magánbiztosító van, mely szektorban fóként brókerek támogatják a politikai biztosítási termékeket. Más szereplőkhöz hasonlóan a magánpiac a fejlődő országokban jelentkező politikai és nemfizetési kockázatok fedezésére összpontosít (MIGA 2013). A legtöbb multilaterális, nemzetközi együttmüködésen alapuló intézmény szintén tagja a Berne Uniónak. A fö multilaterális tagintézmények a következők: Afrikai Kereskedelmi Finanszírozási Intézmény (African Trade Insurance Agency - ATI), Ázsiai Fejlesztési Bank (Asian Development Bank), Amerika-közi Fejlesztési Bank (Inter-American Development Bank), az Arab Befektetési és Export Hitelgarancia Vállalat (Arab Investment and Export Credit Guarantee Corporation Dhaman), az Iszlám Befektetési és Export Hitel Együttmüködés (Islamic Corporation for the Insurance of Investment and Export Credit - ICIEC) és Multilaterális Befektetési Garancia Ügynökség (Multilateral Investment Guarantee Agency - MIGA) (The Berne Union, 2016). A nagyobb viszontbiztositó Berne Unió-tagvállalatok a németországi Munich Reés Hannover Re, a svájci Swiss Re, az USA-beli Berkshire Hathaway/General Re. Ezek a vállalatok kereskedelmi és befektetési biztosítást egyaránt nyújtanak (MIGA, 2013).

\subsection{A politikai biztosítás aktuális üzleti trendjei: csökkenő fedezettség, növekvőkárkifizetések}

A PKB üzletág elemzésére a Berne Unió legfrissebben elérhető, 2016-os éves jelentését használjuk, amely a 2015-ös üzleti év adatait tartalmazza (The Berne Union, 2016). A PKB üzletág trendjeit tekintve azt látjuk, hogy 2015-ben 7 százalékkal, 1996 milliárd USD-ről 1865 milliárd USD-re csökkent a Berne Unió tagjai által nyújtott exporthitel- és befektetési biztosítás volumene, ami azonban továbbra is a teljes nemzetközi kereskedelem 15 százalékát teszi ki. A kárkifizetésekben ellentétes mozgás volt megfigyelhető: 2014-ről 2015-re 35 százalékkal nőttek a Berne Unió tagjainak kárfizetései, miközben a biztosítók által realizált megtérülés 10 százalékkal csökkent. Az összes kifizetett kár 6,271 milliárd USD volt, miközben 2,776 milliárd USD-nyi megtérülés keletkezett. A kárkifizetések növekedése a Berne Unió jelentése szerint az arab tavasz utóhatásainak (elsősorban Líbiában), a venezuelai eseményeknek és az Ukrajnában dúló háborúnak köszönhető. Ugyanakkor a kárkifizetések megnövekedésének ellenére is a veszteség-prémium arány átlagban a 10-20 százalékos sávban maradt rendszerszinten.

A Berne Unió tagjai három fö biztosítási típust kínálnak. Van rövid lejáratú (short term ST), közép- és hosszú lejáratú exporthitel biztosítás (medium and long-term - MLT), valamint 
befektetési és egyéb határokon átnyúló kockázatokat (investment - INV) mérséklő biztosítás. A 8. ábra azt mutatja, hogy az elmúlt öt évben hogyan alakult piaci szegmensenként az új PKB üzleti volumen.

\section{8. ábra: Új PKB üzleti volumenek üzleti szegmensenként bontva}

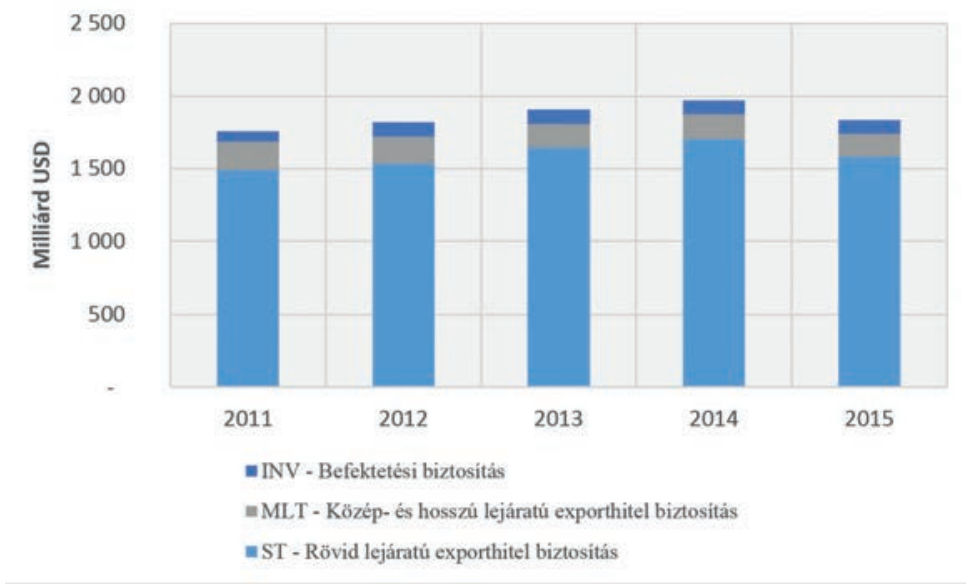

Forrás: Berne Unió (The Berne Union, 2016)

A 2011 és 2014 között tapasztalt növekedés után 2014-ről 2015-re csökkenés volt megfigyelhető. A rövid lejáratú exporthitel biztosítás teszi ki a legnagyobb részét a teljes állománynak, így annak a változásai tükröződnek leginkább a teljes volumen változásában. A további két típusból a közép- és hosszú lejáratú exporthitel teszi ki a nagyobb részt, míg a befektetési és egyéb határon átnyúló biztosítás a kisebbik részt.

\section{Nőttek a Berne Unió tagjainak kárfizetései, miközben a biz- tosítók által realizált megtérülés $10 \%$-kal csökkent.}

A rövid lejáratú üzletágban a biztosított fizetési időszakok egy éven belüliek, jellemzően 30, 60 vagy 90 napot fednek le. Ezek a biztosítások leszállítási kockázatot fedeznek, mint például fogyasztói áruk és nyersanyagrakományok leszállítási kockázatát. Továbbá ezek a biztosítási ügyletek védelmet nyújtanak gazdasági környezetbeli és piaci ármozgások okozta változások ellen is. A teljes szektor csökkenésével összhangban, a rövid lejáratú üzleti szegmens volumene is 7 százalékkal csökkent 2015-ben, 1568 milliárd USD-re. Mindeközben a fizetett kárösszegek szignifikánsan nőttek, 2,019 milliárd USD-ről 2,584 milliárd USDre, ami 39 százalékos növekedést jelent. Az öt legnagyobb kárfizetésủ ország sorrendben: Oroszország (237 millió USD), Brazília (205 millió USD), Venezuela (203 millió USD), USA (161 millió USD) és Szaúd-Arábia (151 millió USD). 
A tipikus alaptevékenységet jelentő, rövid lejáratú exporthitel biztosítások mellett az Exporthitel Ügynökségek közép- és hosszú távú üzleti szegmensekben is biztosítanak szolgáltatásokat. 2015-ben a közép- és hosszú távú (MLT) biztosítások az új üzleti tevékenység 6,9 százalékát, a teljes kitettségnek pedig a 9,4 százalékát fedték le. 2015-ben az MLT szektor biztosítási volumene 7 százalékkal, 154 milliárd USD-re csökkent, mindeközben a teljes kitettség meghaladta a 708 milliárd USD-t. A geopolitikai konfliktusok következtében a kárkifizetésekben szignifikáns növekedés volt tapasztalható: 2014-ről 2015-re 51 százalékos növekedés volt, és elérte a 3,251 milliárd USD-t. A 3. táblázat a rövid távú (ST) és közép- és hosszú távú (MLT) kárfizetésekben leginkább érintett országokat tartalmazza 2014-re és 2015-re vonatkozóan. Az öt legtöbb kárfizetéssel érintett ország az MLT szegmensre a következők voltak: Oroszország (1449 millió USD), Irán (375 millió USD), USA (301 millió USD), Brazília (193 millió USD) és Ukrajna (168 millió USD).

3. táblázat: Top 5 ország: 2014-ös és 2015-ös kárfizetések a rövid távú (ST) és közép-és hosszú távú (MLT) exporthitel biztosítási szegmensekben

\begin{tabular}{|lcc|}
\hline \multicolumn{3}{|c|}{$\begin{array}{c}\text { Kifizzett károk összege az ST } \\
\text { üzletágban (millió USD) }\end{array}$} \\
\hline & $\mathbf{2 0 1 4}$ & $\mathbf{2 0 1 5}$ \\
\hline Oroszország & 76 & 237 \\
\hline Brazilia & 89 & 205 \\
\hline Venezuela & 173 & 203 \\
\hline USA & 165 & 161 \\
\hline Szaúd-Arábia & 11 & 151 \\
\hline
\end{tabular}

\begin{tabular}{|lcc|}
\hline \multicolumn{2}{|c|}{$\begin{array}{c}\text { Kifizett károk összege az MLT } \\
\text { üzletágban (millió USD) }\end{array}$} \\
\hline & $\mathbf{2 0 1 4}$ & $\mathbf{2 0 1 5}$ \\
\hline Oroszország & 172 & 1449 \\
\hline Irán & 893 & 375 \\
\hline USA & 169 & 301 \\
\hline Brazília & 83 & 193 \\
\hline Ukrajna & 132 & 168 \\
\hline
\end{tabular}

Forrás: Berne Unió (The Berne Union, 2016)

A Berne Unió tagjai befektetésekre vonatkozó hitelbiztosítást is nyújtanak ajellemző politikai kockázati események ellen, úgymint politikai büncselekmény, katonai agresszió és megszállás, eltulajdonítás, államosítás, kiutalás és devizakonvertibilitási kockázatok miatti kitettség. A befektetési hitelbiztosítások védelmet nyújtanak a szuverén csődök ellen, amikor az adott nemzeti kormányzat vagy nem képes, vagy nem hajlandó teljesíteni költségvetési kötelezettségeit vagy megfizetni a külföldi adósságfizetési kötelezettségeit.

A legtöbb kártérítést az olyan események után fizették, mint az arab tavasz, amely nagymértékben károsította a külföldi befektetéseket, különösen Líbiában. A politikai instabilitás és bizonytalanság várhatóan fennmarad a közeljövőben, emellett az alacsony olajárak továbbra is visszatartják a líbiai fellendülést. A kelet-ukrajnai fegyveres konfliktus, a venezuelai gazdasági és politikai krízis és az Oroszország elleni szankciók is számos kárkifizetést váltottak ki a Berne Unió tagjai részéről. A nyersanyagárak csökkenése a szubszaharai régióban okozott komoly 
gazdasági válságot. Angolában és Nigériában a kormányzati bevételek szorosan együtt mozognak az olajárakkal, ami ezeket az országokat nagyon sérülékennyé teszi az alacsony olajárral kísért időszakokban (European Commission, 2016). A 9. ábra bemutatja azt a tíz országot, amelyekkel kapcsolatosan a legtöbb kárkifizetés történt 2015-ben politikai és gazdasági fejleményeknek köszönhetően. A legnagyobb kártalanítások a következő országokban fordultak elő: Líbia (34 millió USD), Nigéria (21 millió USD), Törökország (16 millió USD), Oroszország (13 millió USD) és Vietnam (11 millió USD) (The Berne Union, 2016).

\section{9. ábra: Top10 ország 2015-ben, amely kapcsán befektetési biztosítási kárkifizetés történt}

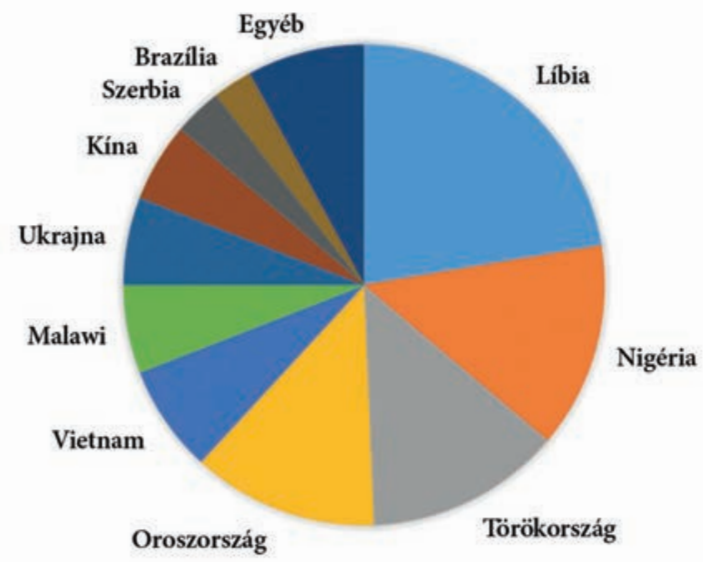

Forrás: Berne Unió (The Berne Union, 2016)

A Politikai Kockázati Biztosítások (PKB) enyhe csökkenésének ellenére a politikai kockázat kezelésének fontos a jövőbeli szerepe a biztosítási piacon. A szakértői várakozások szerint a biztosítási szolgáltatók növelhetik a vonatkozó kapacitásaikat, és intenzívebbé tehetik a következő években az üzleti aktivitást.

\section{5. Összegzés}

Cikkünkben két országkockázati mérőszámot elemeztünk: piaci kockázati alapon mért szuverén kockázati mutatószámokat, amelyek közelítik az országkockázatot és az országkockázati minősítéseket. Statisztikai adatok használatával elemeztük a CDS-felárak és az úgynevezett GI mutatók (az IHS elemző cég országkockázati minősítése) közötti kapcsolatot és a két kockázati mérték hosszú távú stabilitását. A lineáris regressziós modell mérsékelt, de szignifikáns, a legtöbb vizsgált ország esetén toleranciasávon belül maradt a korreláció. Ugyanakkor találtunk néhány kiugró országot: egyrészt olyat, ahol a geopolitikai kockázatértékelés sokkal jobb értéket mutat, mint a gazdasági-piaci indikátorok, másrészt olyat, 
ahol a politikai kockázati értékelés rossz, stabil gazdasági-piaci státusz mellett is. Például Görögország az első csoporthoz tartozik, míg Egyiptom a másodikhoz. Ezen országok esetén a két kockázati mérték szignifikánsan eltérő képet mutat. Összehasonlítva a hosszú távú stabilitást, a GI politikai országkockázati mutató sokkal stabilabb a gazdasági sokkok mellett is, mint a CDS-felár. A növekvő geopolitikai kockázat következtében a politikai kockázatok mérséklése prioritást jelent a befektetők és a hitelezők számára. A cikk utolsó fejezetében átfogó képet adtunk a politikai kockázati biztosítási piacról, mely szektor hatásos garanciákat és biztosítási termékeket nyújt az országkockázati kitettségekkel szemben. A pénzügyi adatok alapján érzékeltettük, hogy a politikai kockázati biztosítási piac növekszik a 2015-ös enyhe visszaesés ellenére is.

\section{NYILATKOZAT}

Ez a cikk kizárólag a szerzők nézeteit tükrözi, amelyek nem feltétlenül egyeznek a MOL Group hivatalos álláspontjával.

\section{IRODALOMJEGYZÉK}

Barro, R. J. 1997. A gazdasági növekedést meghatározó tényezők, Nemzeti Tankönyvkiadó Rt., Budapest, 2005

Berman, D., 2005. The relationship between CDS and bond spreads, The Treasurer, May 2005, pp. 50-52.

Bouchet, M. H.-Clark, E.-Groslambert, B., 2003. Country Risk Assessment: A Guide to Global Investment Strategy, John Wiley \& Sons Ltd, The Atrium, Southern Gate, Chichester, West Sussex PO19 8SQ, England

Brealey, R. A.-Myers, S. C, 2005. Principles of Corporate Finance, 7th Edition, https://doi.org/10.2307/2327568

Damodaran, A., 2015. Country Risk: Determinants, Measures and Implications - The 2015 Edition, Stern School of Business, http://pages.stern.nyu.edu/ adamodar/, https://doi.org/10.2139/ssrn.2630871

Erb, C. B.-Harvey, C. R.-Viskanta T. E., 1996. Political Risk, Economic Risk and Financial Risk, Fuqua School of Business Working Paper No. 9606, https://doi.org/10.2469/faj.v52.n6.2038

European Commission, 2016. Impact of low oil prices on oil exporting countries, JRC SCIENCE FOR POLICY REPORT

Gallagher, 2014. Credit and Political Risk Insurance Report and Market Update, July 2014

Gyarmati, Á.-Medvegyev, P., 2011. Válság és hitelderivatívák, A szintetikus fedezett adósságkötelezettségek (CDO-k) árazása és kockázataik, Közgazdasági Szemle, LVIII. évfolyam, 2011. November, pp. 949-969.

Heinrichs, M.-Stanoeva, I., 2012. Country risk and sovereign risk - building clearer borders, Euromoney Handbooks, Chapter 3, pp. 15-24.

Hull, J.-Predescu, M.-White, A., 2003. The relationship between credit default swap spreads, bond yields, and credit rating announcements, University of Toronto, https://doi.org/10.2139/ssrn.2173171

IHS, 2017. IHS Country Risk Ratings - Strategic Risk Methodology, accessed 17 January 2017, http://connect.ihs.com

Iranzo, S., 2008. Delving Into Country Risk, Banco de Espana Eurosistema, Madrid, Documentos Ocasionales N. 0802, https://doi.org/10.2139/ssrn.1120723

Kansal, V., 2015. Political Risk: Conceptualization, Definition, Categorization, and Methodologies, Journal of Political Risk, Vol. 3, No. 4, April 2015.

Marsh Political Risk Map, 2017. https://www.marsh.com/us/campaigns/political-risk-map-2017.html, accessed 10 April 2017 MIGA, 2013. WIPR (World Investment and Political Risk) report

The Berne Union, 2016. The Yearbook 2016, http://www.berneunion.org/wp-content/uploads/2012/10/BU-Yearbook-2016.pdf 
